\title{
Discours
}

Revue de linguistique, psycholinguistique et

informatique. A journal of linguistics, psycholinguistics and computational linguistics

$23 \mid 2018$

Varia

\section{Narrative Skills of Bilingual Children with Autism Spectrum Disorder}

Huong Hoang, Ana Maria Gonzalez-Barrero and Aparna Nadig

\section{OpenEdition}

Journals

Electronic version

URL: http://journals.openedition.org/discours/9856

DOI: $10.4000 /$ discours.9856

ISSN: 1963-1723

Publisher:

Laboratoire LATTICE, Presses universitaires de Caen

\section{Electronic reference}

Huong Hoang, Ana Maria Gonzalez-Barrero and Aparna Nadig, « Narrative Skills of Bilingual Children with Autism Spectrum Disorder », Discours [Online], 23 | 2018, Online since 21 December 2018 connection on 13 June 2019. URL : http://journals.openedition.org/discours/9856 ; DOI : 10.4000/ discours.9856 



\section{discours}

\section{Revue de linguistique, psycholinguistique et informatique}

\section{Narrative Skills of Bilingual Children with Autism Spectrum Disorder}

\section{Huong Hoang}

School of Communication Sciences and Disorders, McGill University, Montreal, Canada

Ana Maria Gonzalez-Barrero

School of Communication Sciences and Disorders, McGill University, Montreal, Canada

Centre for Research on Brain, Language, and Music (CRBLM), Montreal, Canada

Aparna Nadig

School of Communication Sciences and Disorders, McGill University, Montreal, Canada

Centre for Research on Brain, Language, and Music (CRBLM), Montreal, Canada

Huong Hoang, Ana Maria Gonzalez-Barrero, Aparna Nadig, «Narrative Skills of Bilingual Children with Autism Spectrum Disorder», Discours [En ligne], 23 | 2018, mis en ligne le 21 décembre 2018.

URL: http://journals.openedition.org/discours/9856

Titre du numéro: Varia

Coordination: Saveria Colonna \& Sarah Schimke

Date de réception de l'article: 22/08/2018

Date d'acceptation de l'article: 19/12/2018 



\title{
Narrative Skills of Bilingual Children with Autism Spectrum Disorder
}

\author{
Huong Hoang \\ School of Communication Sciences and Disorders \\ McGill University, Montreal, Canada \\ Ana Maria Gonzalez-Barrero \\ School of Communication Sciences and Disorders \\ McGill University, Montreal, Canada \\ Centre for Research on Brain, Language, and Music (CRBLM) \\ Montreal, Canada \\ Aparna Nadig \\ School of Communication Sciences and Disorders \\ McGill University, Montreal, Canada \\ Centre for Research on Brain, Language, and Music (CRBLM) \\ Montreal, Canada
}

\begin{abstract}
The study investigated how narratives are influenced by both autism spectrum disorder (ASD) and bilingualism. We analyzed the short narratives of school-age Quebec French-speaking children: bilinguals with and without ASD, and monolinguals with and without ASD. Children were given sets of three picture cards depicting a scenario, and were asked to sequence the cards and tell a story. We measured: (1) language production (number of utterances, total number of words), (2) macrostructure (appropriate sequencing of events, number of events mentioned, coherence), (3) microstructure (character introductions, maintenance of referential terms, use of grammatical gender, use of connectives), and (4) evaluative devices (both linguistic and non-linguistic), and mental state terms. With respect to language production, bilinguals produced more utterances than monolinguals, despite having marginally lower receptive vocabulary scores in French. With respect to macrostructure, typically-developing children provided more coherent narratives. No significant differences were found on microstructure or evaluative devices, but evaluative devices were infrequent for all groups. There were no decrements in the narratives of bilingual children relative to monolingual children, both with and without ASD; in fact we found an increased number of utterances in the narratives of bilinguals. The current findings suggest that bilingualism does not negatively affect narrative skills in children with ASD.
\end{abstract}

Keywords: autism spectrum disorder (ASD), bilingualism, narrative, picture-sequencing task, macrostructure, microstructure, elaborations

\section{Introduction}

Views on bilingualism have shifted drastically over the past half-century. Historically, it has been argued that learning two languages confused children and delayed language development (Barac et al., 2014). However, past methodologies often 
failed to provide a clear, quantified definition of bilingualism or take into account discrepancies in a range of factors affecting amount of language exposure (e.g., socio-economic status). Peal and Lambert's (1962) study, which carefully matched monolingual and bilingual groups on socio-economic status, age and language proficiency, was one of the first to suggest that bilingualism was not linked to a negative outcome. Although reduced language exposure may result in an initial lag in syntax, morphology and vocabulary in any one language, the majority of present studies have shown that early bilinguals are eventually able to attain skills equal to monolinguals (Blom, 2010; Nicoladis \& Genesee, 1997; Kimbrough Oller, 2005; Paradis et al., 2011; Pearson et al., 1993; Thordardottir, 2011). In fact, bilingualism may even contribute to more advantages than disadvantages later in life (Bialystok et al., 2016; Buchweitz \& Prat, 2013; Goetz, 2003).

Yet, the common belief that bilingualism is detrimental to language development continues to persist when it comes to children with neurodevelopmental disorders such as autism spectrum disorders (ASD). According to the Diagnostic and Statistical Manual of Mental Disorders: DSM-5, ASD is characterized by impaired social communication and interaction as well as restricted and repetitive patterns of interests and behaviors (American Psychiatric Association, 2013). Though not necessary for diagnosis, more than half of young children with ASD present with significant language delays (Ellis Weismer \& Kover, 2015; Pickles et al., 2014). Consequently, professionals often recommended limiting language input to only one language to "ease" the task of language learning (as cited by Kay-Raining Bird et al., 2012; Kremer-Sadlik, 2005).

Interestingly, with respect to children with ASD as well, evidence does not support concerns regarding bilingualism. Recent studies have demonstrated that bilingually-exposed children with ASD do not present with additional language delays when compared with monolingual children with ASD (for reviews see Drysdale et al., 2015; Kay-Raining Bird et al., 2016; Lund et al., 2017; Gonzalez-Barrero $\&$ Nadig under review). For example, comparable performance has been found for bilingual and monolingual toddlers with ASD on early language milestones such as age of first words and vocabulary knowledge (Hambly \& Fombonne, 2012; Valicenti-McDermott et al., 2013). However, most evidence on language development in bilingually-exposed children with ASD to date has examined the early stages of language development prior to age 6 using standardized measures, and we know very little about more sophisticated aspects of language use (i.e., discourse, narrative). In the present study we analyze the short narratives produced by four groups of school-age Quebec French-speaking children: bilingual and monolingual children with ASD, and bilingual and monolingual typically-developing children in a picture-sequencing task.

Creating a narrative requires the coordination of multiple levels of language. The broadest level, called macrostructure, refers to the global coherence of the narrative. Conversely, microstructure is defined by smaller linguistic levels (i.e., anaphoric reference, the use of connectives) necessary in maintaining local cohesion 
throughout the narrative (Hickmann, 1995). Storytellers can choose to elaborate their narrative by incorporating mental state terms, character speech, onomatopoeia, and emphatic markers, or non-linguistically through gestures and changes in prosody (Labov \& Waletzky, 1967; Reilly et al., 1990). Therefore, the analysis of narratives allows for the study of a diverse range of language skills, some of which may be impacted by bilingualism and/or having an ASD. First, we sketch an outline of the general profile of narrative skills for typically-developing (TD) monolingual children, followed by a review of how these skills differ in bilingual and ASD populations. Then, we provide predictions for narrative skills in bilingual children with ASD.

\subsection{Narrative skills in typically-developing monolingual children}

\subsubsection{Macrostructure}

Macrostructure refers to the global coherence of a narrative (Pearson \& Villiers, 2005), comprising of a causal sequence of events and their organization around a central theme. Monolingual children show evidence of narrative structure at approximately 5 years of age (Berman, 2009; Berman \& Slobin, 1994). Children are initially able to tell stories from pictures depicting two or three events. Expressing causal connections between story events, however, continues to develop over the course of childhood. At approximately 9 years of age, children are capable of maintaining causal structure throughout the narrative by stating the character's goal, outlining the character's attempt to complete that goal, and determining the outcome of actions (Berman \& Slobin, 1994; Stein \& Glenn, 1979). Children's renditions of outcomes are less sophisticated than that of adults, and tend to be the last component acquired.

\subsubsection{Microstructure}

Microstructure refers to the local cohesion within the story (Pearson \& Villiers, 2005). Children must show mastery of semantic, syntactic, and morphosyntactic structure to ensure that the story is well understood by their listener. This can be achieved by being sensitive to mutual knowledge shared with the listener, giving the appropriate amount of information when first introducing the character, and then maintaining reference (in accordance to gender and number) throughout the story (Hickmann, 1995; Hickmann et al., 1995; Wigglesworth, 1990). Karmiloff-Smith (1981 and 1986) studied discourse devices in English and French narratives of children from 4 years of age to 9 years of age, and summarized a course of development in the use of articles and pronouns to maintain reference. In the first stage, characters were first mentioned by a definite article, and subsequent pronouns were used but in a deictic manner. In the later stages, children used a thematic subject strategy, in which they introduced characters with indefinite determiners (e.g., Il y avait un petit garçon; Karmiloff-Smith, 1986), and then subsequently referred to them using pronouns in the subject position (e.g., Il voulait voir le ballon; Karmiloff-Smith, 1986). Mastery of reference maintenance in a narrative context does not occur until very late in 
childhood (Hickmann, 1995; Vion \& Colas, 1999; Wigglesworth, 1990). A high degree of syntactic complexity through coordination, subordination, and use of connectives (e.g., puis, parce que, mais, etc.) is necessary in linking sentences and locally "knitting the fabric" (Berman \& Slobin, 1994: 19) of the narrative. Frequency of connective use increases with age (Peterson \& McCabe, 1991), and becomes more sophisticated over time. For example, the connective et pis is often used by preschoolers to connect two propositions together (Jisa, 1984). On the other hand, older children either use subordination in place of $e t$ pis, or employ a more diverse repertoire of connectives conveying specific relationships (e.g., the adversative mais, causal parce que) as a strategy instead (Vion \& Colas, 2005).

\subsubsection{Evaluative devices}

In addition, children may use evaluative devices to engage the listener's attention. Labov and Waletzky (1967) defined evaluative devices that go beyond the pictures explicitly depicted in the picture story. This includes emphatics and intensifiers that catch the audience's attention (e.g., repetition, la plante grossit et grossit), character speech, onomatopoeia, and sound effects (e.g., ouch, boom) to vividly "show" rather than "tell" the narrative (Reilly et al., 1990).

Children may also evaluate their narrative using mental state language, which indicates a character's feelings, intentions and motivations. Use of mental state terms begins developing in tandem with theory of mind abilities, with desire and emotional terms being the first acquired (Bartsch \& Wellman, 1995; Fenson et al., 1994). Distribution of evaluative devices changes over time (Bamberg \& Damrad-Frye, 1991), and growth of mental state terms continues to extend into adulthood (Pearson, 2001). Whereas 5 -year-olds use an equal proportion of evaluative devices to 9-year-olds and adults, older participants tend to use more emotional mental state terms than younger participants. Younger children use emotional evaluations in a local fashion, focusing on the emotion depicted in one picture, rather than taking into account the context of the entire story (Bamberg \& Damrad-Frye, 1991; Bamberg \& Reilly, 1996). Non-linguistic evaluative devices, such as changes in prosody, facial expressions, and gestures, tend to be favored at a young age. While 7 -year-olds are just beginning to use linguistic elaborations in their narratives, 11-year-olds are capable of switching between the two modalities depending on their audience (Reilly et al., 1990; Bamberg \& Reilly, 1996).

Overall, the development of macrostructure, microstructure and use of evaluative devices occurs gradually, and refinement of these skills extends into adulthood.

\subsection{Narrative skills in bilingual children}

Bilingual children develop similarly to monolinguals in language aspects, but may be initially delayed in development due to reduced exposure to each language (Blom, 2010; Nicoladis \& Genesee, 1997; Kimbrough Oller, 2005; Paradis et al., 2011; Pearson et al., 1993; Thordardottir, 2011). Thus, a delay in narrative skills, which are 
heavily dependent on language ability, may be observed as well. Previous literature at each narrative level is reviewed to explore this topic.

\subsubsection{Macrostructure}

In terms of macrostructure, bilingual children follow a similar pattern of development to monolingual children. Many studies show no statistically significant differences in macrostructure components when comparing monolingual and bilingual school-aged children (Kunnari et al., 2016; Squires et al., 2014). It was suggested that the lack of differences between groups is due to the cross-language transfer of macrostructure. The global organization of narratives is more or less similar regardless of the language spoken, especially between languages occupying the same sociocultural context and status (Kunnari et al., 2016). Thus, macrostructure skills are not affected by language-dependent factors such as amount of language exposure, and they can easily transfer across languages.

Investigations of children with language impairment have further suggested that macrostructure knowledge develops independently from input-dependent lexicon and morphosyntax (Iluz-Cohen \& Walters, 2012). When comparing TD bilingual children and bilingual children with language impairment, both groups performed similarly on macrostructure content. One study even reported a positive effect of bilingualism on macrostructure, where bilingual groups (TD children and children with specific language impairment) performed better than monolingual language-matched controls (Tsimpli et al., 2016). The authors attributed this to the bilingual children's heightened ability to "abstract language-independent narrative properties, thus making narrative structure and coherence more accessible to bilingual children" (Tsimpli et al., 2016: 210).

\subsubsection{Microstructure}

Microstructure, on the other hand, depends heavily on language exposure (Blom, 2010; Nicoladis \& Genesee, 1997; Kimbrough Oller, 2005; Paradis et al., 2011; Pearson et al., 1993; Thordardottir, 2011), and does not transfer between languages (Paradis \& Genesee, 1996). Thus, microstructure skills in this area may be reduced in bilinguals due to reduced exposure in each language. Pearson (2002) found a significant difference in narrative scores at 2nd grade between English-Spanish bilinguals and monolinguals in the United States, but this difference decreased by the time they reached 5th grade. Furthermore, the societal context of bilingualism can have an additional impact on microstructure. Uccelli and Paéz (2007) found that low-SES (socioeconomic status) English-Spanish bilinguals lagged behind monolingual peers in their microstructure scores. Larger vocabularies in English were positively correlated with higher narrative quality scores in English. Uccelli and Paéz (2007) attributed delays in vocabulary not just to the division of language exposure due to bilingualism, but also to reduced language exposure in a low-SES environment. These studies suggest that microstructure incorporates many aspects of linguistic knowledge that necessitate more language exposure to grow over time. 


\subsubsection{Evaluative devices}

Chen and Yan (2011) measured the use of evaluative devices defined by Labov and Waletzky (1967) (i.e., comments describing beyond what is explicitly depicted), and found bilinguals used more evaluative clauses than monolinguals. Although not formally measured, it was noted that French-English bilingual children use an animated storytelling style conveyed through elaborations in addition to shifts in tense (Hoang et al., 2015). However, it is unclear whether this is from the influence of the French-Canadian culture in the region, or an effect of bilingualism. As for mental states, Tsimpli et al. (2016) reported that TD bilingual children used more emotional- and cognition- mental state terms than monolinguals, whereas Kunnari et al. (2016) reported no differences in the frequency of use of such terms between their samples of monolinguals and bilinguals. In summary, there are few comparisons of the use of evaluative devices and mental state terms between bilingual and monolingual children, but available reports suggest that bilinguals may provide relatively more evaluative devices.

\subsection{Narrative skills in children with ASD}

\subsubsection{Macrostructure}

Overall, findings highlight nuanced differences between TD children and children with ASD in narrative skills. Norbury and Bishop (2003) found that children with language impairment, TD children and children with ASD performed equally when identifying the main components of macrostructure. Diehl et al. (2006) also reported that ASD narratives possessed basic macrostructure elements, but lacked story coherence. Children with ASD are able to enumerate the main story events and express the general theme of the story (Loveland et al., 1990; Losh \& Capps, 2003). However, they may insert bizarre or irrelevant details into their narrative, and provide fewer causal explanations to link the events. Children with ASD are able to identify key events in the story; however, narratives may lack coherence and contain irrelevant details. Confirming these reports, a recent meta-analysis exploring narratives of children with ASD (who did not have intellectual disability) revealed poor performance in areas of story grammar and story cohesion compared to TD peers (Baixauli et al., 2016).

\subsubsection{Microstructure}

With respect to microstructure, a meta-analysis of children with ASD demonstrated significantly reduced narrative length, lexical diversity, syntactic complexity and use of grammatical forms relative to TD controls (Baixauli et al., 2016). However, it is important to recognize the high rate of comorbidity between language impairment and ASD (Pickles et al., 2014). Thus, low performance on grammar, morphosyntax and syntactic structure - key components in maintaining microstructure - would follow from language impairment, rather than ASD per se, as confirmed by the studies reported below. 


\subsubsection{Studies with children with ASD who have lower language abilities}

17 Mixed results were reported for microstructure when children were not matched for language ability. In a storybook context, children with ASD performed equally to TD children in the use of coordinate clauses, relative clauses and complements (Losh \& Capps, 2003). However, reference maintenance of children with ASD paralleled abilities of children with specific language impairment. Both groups were less consistent in maintaining reference compared to TD children (Norbury $\&$ Bishop, 2003). TD children used indefinite articles to introduce their characters, which signals adaptation to the listener who did not already know the characters. On the other hand, ASD and specific language impairment groups used an equal proportion of indefinite and definite articles. Both groups also had a higher proportion of ambiguous nouns and errors in tense use than TD children.

\subsubsection{Studies with children with ASD who have similar language abilities}

Diehl et al. (2006) matched TD and children with ASD on expressive and receptive language abilities, age, gender, and cognitive abilities. No significant differences were observed in terms of syntactic complexity. Capps et al. (2000) found contrasting results: TD children used a higher proportion of complex syntax compared to children with ASD when matched for mental age, intelligence quotient (IQ) and language level.

\subsubsection{Evaluative devices}

Children with ASD use an equal proportion of evaluative devices as TD controls (Tager-Flusberg, 1995; Losh \& Capps, 2003; Norbury \& Bishop, 2003); however, TD controls employ a larger variety of attention-getters than ASD and developmentally delayed children (Capps et al., 2000), using intensifiers, sound effects, and character speech to draw attention. On the other hand, children with ASD used concrete directives like "look at that!". Losh and Capps (2003) found that the diversity of evaluations was positively correlated with the ability to identify and define emotions. They suggest that verbal children with ASD may have more access to emotional knowledge, aiding them in using more mental state terms in their narratives (Losh \& Capps, 2003). Baixauli et al.'s (2016) meta-analysis indicates a reduced mental state terms usage in children with ASD relative to TD controls, however group differences are eliminated when groups are matched on language ability (Bang et al., 2013; Capps et al., 2000; Tager-Flusberg, 1995; Tager-Flusberg \& Sullivan, 1995).

One prior study explored the interaction between bilingualism and ASD, as we do, in Greek-speaking children from 7 to 11 years old (Baldimtsi et al., 2016). Participants were matched on age and performance IQ. Verbal IQ tended to be lower in the ASD groups, and degree of autism symptoms and potential SES difference between monolingual and bilingual ASD groups were not reported. These authors found that their sample of bilinguals with ASD outperformed monolinguals with ASD with respect to story structure complexity, and used marginally fewer ambiguous 
referential forms. Monolingual children with ASD produced a lower proportion of coordinate and subordinate sentences than TD monolinguals; conversely, they also produced more physiological and perceptual verbs and adjectives than TD monolingual children. This last finding suggests that monolinguals with ASD may have described picture stimuli in more perceptual detail than TD monolinguals, while focusing less on linking the pictures together into a narrative.

\section{The present study}

In the present study, we compare the narratives of four groups of participants, as elicited by a picture-sequencing task: French-speaking monolingual children who have ASD or who are TD, and French-English bilingual children with ASD or who are TD. Narrative ability was assessed with respect to the macrostructure, microstructure, and use of evaluative devices. Picture-sequencing tasks help to decrease cognitive load by scaffolding basic macrostructure components. We acknowledge that picture sequences elicit simpler narratives than picture book reading for example (Kristen et al., 2015; Spinillo \& Pinto, 1994); however, the narrative levels of interest are still present for analysis (Shapiro \& Hudson, 1991). Through this analysis we hope to gain a clearer understanding of how bilingualism affects narrative skills, and expressive language more broadly, in children with and without ASD.

\subsection{Predictions}

Macrostructure ASD: Based on prior work (Baixauli et al., 2016; Losh \& Capps, 2003) we expect children with ASD to perform equally well to TD children on outlining the main plot of the story, but to lack story coherence.

Macrostructure Bilingualism: Based on previous research indicating that bilinguals are able to transfer macrostructure skills between their two languages (Iluz-Cohen \& Walters, 2012; Squires et al., 2014), we expect TD monolingual and bilingual children to perform equally well on story macrostructure.

Microstructure ASD: When children with ASD have lower language levels than TD children, their narratives have found to be less syntactically complex and they are less consistent in referencing (Losh \& Capps, 2003; Norbury \& Bishop, 2003).

Microstructure Bilingualism: Considering that bilinguals have relatively less exposure to each language, their knowledge on language-specific grammar and vocabulary is likely to be reduced (Paradis et al., 2011; Thordardottir, 2011). Thus, we expect story microstructure will be less complex in narratives produced by bilinguals compared to their monolingual counterparts.

Evaluative devices $A S D$ : Prior work indicates a slightly lower proportion of mental state terms (Baixauli et al., 2016) produced by children with ASD. However, other evaluative devices are similar in frequency, but may exhibit less diversity than observed in controls (Capps et al., 2000). 
Evaluative devices Bilingualism: There is some indication that TD bilingual children may use more evaluative devices in their narratives than monolingual children (Chen \& Yan, 2011). However, it is unclear whether this is attributed to cultural differences in storytelling or effect of bilingualism.

\section{Methods}

\subsection{Participants}

This study was part of a larger project examining cognitive and language skills in monolingual and bilingual children with ASD, which included a large battery of tests (e.g., executive function, sentence repetition, receptive vocabulary, etc.). Twenty children ( 15 males, 5 females) with a mean age of 8 years and 1 month $(S D=8.15$ months) participated in the current study. Five children were included in each of the four cells of the study design: bilingual/monolingual $\times \mathrm{ASD} / \mathrm{TD}$. Ethics approval was obtained from a university institutional review board. Participants were recruited from schools, therapy clinics, autism organizations, and a database from previous studies.

The study was conducted in Montreal, Canada, where French is the official language of the province, while both English and French are official languages of the country. Monolingual participants were speakers of French; bilingual participants dominant language was French and their non-dominant language was English $(n=5)$, Russian $(n=1)$ or Spanish $(n=4)$. In this study, bilingual status was rigorously defined as proficient bilingualism based on four factors: 1) history or current exposure to an L2 greater than $20 \%, 2$ ) obtained a proficiency score from their parents of 3 or 4 in both languages on a 4-point scale, 3) could complete at least 5 out of 8 tasks of the larger study protocol in both languages, 4) obtained a proficiency score of 3 or 4 in both languages from 3 external raters on a 4-point scale based on oral skills from video recordings. Children who met the criteria just described were retained in the bilingual group, regardless of age of first exposure to an L2 or varied language exposure patterns. Conversely, monolingual participants were those who had a history of exposure to an L2 of less than $20 \%$.

Nonverbal IQ (NVIQ) was assessed using the Leiter-R (Roid \& Miller, 1997) and only children with scores greater than 80 were included in the study. Children with ASD had a clinical diagnosis from licensed clinicians or multidisciplinary groups of specialists from health care institutions. To confirm ASD symptomatology, the Social Communication Questionnaire (SCQ; Rutter et al., 2003) was administered. Demographic information and group matching results are presented in Table 6 in the Appendix. The four groups of children did not differ significantly on age, NVIQ, and maternal education (as a proxy for SES). Monolinguals and bilinguals with ASD did not differ significantly with respect to autism symptoms. Receptive vocabulary was marginally higher in the TD versus ASD bilingual groups, whereas TD and ASD monolingual groups did not differ significantly with respect to receptive vocabulary. As would be expected based on language exposure, monolinguals had higher receptive vocabulary scores than bilinguals. 
Language impairment (LI) was determined based on low performance (-1SD) on a sentence repetition subtest in the dominant language (recalling sentences subtest from the Clinical Evaluation of Language Fundamentals CELF-4 in French: CELF CDN-F; Secord et al., 2009). Sentence repetition is considered an accurate marker for LI (Archibald \& Joanisse, 2009; Conti-Ramsden et al., 2001), with a cutoff of -1SD showing adequate sensitivity and specificity for the identification of LI (Thordardottir et al., 2011). In each of the monolingual ASD and bilingual ASD groups, one child met this criteria for LI.

\begin{tabular}{|c|c|c|c|c|c|c|}
\hline & $\begin{array}{l}\mathrm{TD} \\
\text { Monolingual } \\
(\mathrm{n}=5) \\
\mathrm{M}(S D)\end{array}$ & $\begin{array}{l}\text { TD } \\
\text { Bilingual } \\
(\mathrm{n}=5) \\
\mathrm{M}(S D)\end{array}$ & $\begin{array}{l}\text { ASD } \\
\text { Monolingual } \\
(\mathrm{n}=5) \\
\mathrm{M}(S D)\end{array}$ & $\begin{array}{l}\text { ASD } \\
\text { Bilingual } \\
(\mathrm{n}=5) \\
\mathrm{M}(S D)\end{array}$ & $p$ & $\begin{array}{l}\text { Partial } \\
\text { eta } \\
\text { squared } \\
\left(n^{2}\right)\end{array}$ \\
\hline $\begin{array}{l}\text { Chronological } \\
\text { age (months) }\end{array}$ & $\begin{array}{l}94.80 \\
(8.37)\end{array}$ & $\begin{array}{l}94.60 \\
(9.18)\end{array}$ & $\begin{array}{r}101.20 \\
(8.90)\end{array}$ & $\begin{array}{l}95.60 \\
(6.73)\end{array}$ & 0.56 & 0.12 \\
\hline NVIQ & $\begin{array}{r}109 \\
(6.12)\end{array}$ & $\begin{array}{r}108 \\
(9.84)\end{array}$ & $\begin{array}{r}113 \\
(8.65)\end{array}$ & $\begin{array}{r}110 \\
(11.74)\end{array}$ & 0.89 & 0.04 \\
\hline $\begin{array}{l}\text { Maternal } \\
\text { education } \\
\text { (years) }\end{array}$ & $\begin{array}{r}14 \\
(2.17)\end{array}$ & $\begin{array}{r}16 \\
(2.05)\end{array}$ & $\begin{array}{r}17 \\
(1.10)\end{array}$ & $\begin{array}{r}15 \\
(3.56)\end{array}$ & 0.23 & 0.23 \\
\hline $\mathrm{SCQ}^{\mathrm{a}}$ & $\begin{array}{r}1.40 \\
(1.14)\end{array}$ & $\begin{array}{r}2.80 \\
(1.30)\end{array}$ & $\begin{array}{l}15.80 \\
(2.95)\end{array}$ & $\begin{array}{l}18.25 \\
(2.06)\end{array}$ & $<0.01$ & 0.95 \\
\hline $\begin{array}{l}\text { Receptive } \\
\text { vocabulary } \\
(\text { EVIP) })^{\text {bcde }}\end{array}$ & $\begin{array}{r}134 \\
(18.21)\end{array}$ & $\begin{array}{r}118 \\
(6.30)\end{array}$ & $\begin{array}{r}123 \\
(13.74)\end{array}$ & $\begin{array}{r}100 \\
(18.37)\end{array}$ & 0.02 & 0.46 \\
\hline $\begin{array}{l}\text { Sentence } \\
\text { repetition }\end{array}$ & $\begin{array}{r}11 \\
(3.29)\end{array}$ & $\begin{array}{r}10 \\
(1.23)\end{array}$ & $\begin{array}{r}11 \\
(3.27)\end{array}$ & $\begin{array}{r}9 \\
(3.58)\end{array}$ & 0.68 & 0.09 \\
\hline
\end{tabular}

a. ASD monolingual and ASD bilingual groups did not differ significantly on autism symptoms on the $S C Q, \mathrm{p}=0.204$.

b. TD monolingual vs. ASD monolingual groups did not differ significantly on receptive vocabulary, $\mathrm{p}=0.321$.

c. TD bilingual vs. ASD bilingual groups were marginally different on receptive vocabulary, $\mathrm{p}=0.069$.

d. ASD bilinguals had marginally lower receptive vocabulary scores in French than ASD monolinguals, $\mathrm{p}=0.05$.

e. TD bilinguals and TD monolinguals did not differ significantly with respect to receptive vocabulary, though there was a trend for monolinguals to perform better, $\mathrm{p}=0.104$.

Table 1 - Participants' demographic characteristics ${ }^{1}$

1. $\mathrm{TD}=$ typically-developing group; $\mathrm{ASD}=$ autism spectrum disorders; $\mathrm{SCQ}=$ Social Communication Questionnaire; "Receptive vocabulary" results from the Échelle de vocabulaire en images Peabody (EVIP); "Sentence repetition subtest" from the Clinical Evaluation of Language Fundamentals (CELF-4). 


\subsection{Procedure}

The study was conducted at a university laboratory or at the child's home. During the narrative task each participant was given 3 sets of picture cards depicting a scenario (i.e., a girl baking a pie, a girl building a sand castle in the beach, and a boy watering his plant; each set contained 3 cards). Children were asked to put the cards in a logical order, and then tell a story based on the sequence of cards. Sessions were video recorded for later analysis. Two research assistants with native proficiency in both French and English transcribed the videos using the CHAT (Codes for the Human Analysis of Transcripts) transcription program (MacWhinney, 2000). Following this, narrative samples were analyzed by the first and second authors of this article. To characterize the narratives, measures of quantity of language production (number of utterances and total number of words) were calculated.

An adapted version of the NSS (Narrative Scoring Scheme), an assessment tool for narratives (Miller et al., 2003), was used to analyze macrostructure and microstructure. Specifically, the items "referencing", "cohesion", "character development" (adapted as "initial character introduction"), and the three main story events (defined in this study as "actions") were coded using the scheme presented in Table 6 found in the Appendix. All items were evaluated on a scale ranging from 0 to $3: 0$ denotes an inaccurate use or absence of elements, whereas 3 denotes a complete description of all the relevant elements of the picture. The first description of the picture sequence was coded, unless the child self-corrected and re-told the story without prompting from the experimenter. In such cases the second version was coded.

\subsection{Macrostructure}

Macrostructure was coded using three measures: a) logical sequencing of the pictures, b) number of main actions recalled, and c) overall coherence of the story. Children were given a maximum of 2 points if they were able to organize the pictures in the correct order. Actions were defined as key elements to the sequence that were explicitly depicted in the picture set. The first and second authors determined acceptable action sequences for each card set (see Table 7 in the Appendix). Children were awarded 1 point for every main action mentioned (i.e., totaling to 3 points for the goal, the attempt and the outcome). Overall coherence of the story was also assessed; 3 points were awarded if the child's story was short, complete, and unambiguous. All three measures were summed into a total macrostructure score of 8 .

\subsection{Microstructure}

The following items were incorporated into the microstructure score: a) initial introductions of the characters, b) use of referential terms for objects and characters, c) use of appropriate gender for reference, and d) use of conjunctions (following Hawkins \& Towell, 2001). Initial introductions of the characters are used to measure whether the child can choose the appropriate form to match the knowledge of the listener (Miller et al., 2003; Schneider \& Hayward, 2010). If children introduced 
the character with a pronoun, they were awarded 1 point (e.g., elle). Mention of the character within a noun phrase granted the child 2 points (e.g., la fille). Any additional information added (e.g., if the child named the character, or added a modifier to the noun phrase) granted the child 3 points (e.g., la petite fille). Reference maintenance was analyzed in accordance to Karmiloff-Smith's (1981 and 1986) course of development. Referential terms for both characters and objects were analyzed. Children were awarded 1 point if they consistently used definite descriptions or pronouns throughout the sequence, with no change in referential terms. 2 points were awarded if the child inconsistently reduced definite and indefinite forms to pronouns. If children appropriately reduced forms to pronouns (e.g., un garçon to $i l$ ), or indefinite forms to definite forms over a sequence (e.g., un garçon to le garçon), they were awarded a maximum of 3 points. 1 point was awarded for every conjunction mentioned, amounting to a total of 2 points for each story. Each repetition of a conjunction was counted (e.g., la fille fait une tarte et elle l'a mange et elle la trouve délicieuse $)^{2}$, and coordinating and subordinating conjunctions were counted equally (see Table 8 in the Appendix for an exhaustive list of conjunctions used in the study). All four measures were summed into a total microstructure score of 10 .

\subsection{Evaluative devices}

Narrative evaluative devices were defined by three measures: a) linguistic evaluative devices, b) nonlinguistic evaluative devices, and c) mental state terms use. Evaluative devices were adapted from Reilly et al. (1990) and from Capps et al. (2000), and redefined into specific categories of linguistic and nonlinguistic evaluative devices. The child may describe something not depicted in the cards (e.g., elle a trouvée la tarte délicieuse), attribute speech to the characters (e.g., miam c'est bon!), use a narrative device to inform the listener of the setting (e.g., il était une fois...), repeat for emphasis (e.g., [la plante] grandit et grandit et grandit), or employ onomatopoeias and sound effects (e.g., ouf, eub, yay, splash). A) 1 point was awarded for each linguistic evaluative device used, with a maximum of 2 points for each story. Nonlinguistic evaluative devices were counted when children went beyond the picture sequence using nonlinguistic expressions, such as gesturing, laughing and/or smiling, and raising their voice to emphasize story elements. B) The child was awarded 1 point for each nonlinguistic evaluative device used, amounting to a total of 2 points for each story. Frequency and type of mental state terms were assessed based on the categorization of Bang et al. (2013). C) The child was awarded 1 point, totaling to 2 points, for every mental state term mentioned (see Table 9 in the Appendix for an exhaustive list of mental state terms observed in narratives). All three measures were summed into a total score of 6 .

Twenty-five percent of the data (12 picture sequences: 3 sequences for each of 4 participants), were double coded by the first and second authors. Inter-rater

2. It should be noted that the examples included in the article are reported as transcribed, with no correction in spelling or grammar to the children's utterances. 
reliability was calculated on the total score and agreement between scores reached 97.6\%. Discrepancies between scores were discussed and resolved through consensus. Data for the remaining participants were then coded by the first author who was blind to both diagnosis and language exposure status.

\section{Results}

Data on each type of measure were submitted to 2 (diagnostic group: TD vs. ASD) by 2 (language exposure group: Monolingual vs. Bilingual) analyses of variance (ANOVAs). To reduce the number of tests conducted, total scores were used for macrostructure, microstructure, and evaluative devices. Measures of effect size are provided for all results, which are important to the interpretation and generalizability of findings especially given our small sample size (e.g., Lakens, 2013).

Table 2 presents measures on the quantity of language production in each group. For number of utterances there was no significant difference between diagnostic groups $\left(F(1.16)=0.79, p=0.39\right.$, partial $\left.n^{2}=0.05\right)$. There was however a significant main effect of language exposure $\left(F(1.16)=5.80, p=0.03\right.$, partial $\left.n^{2}=0.27\right)$, with bilingual groups obtaining higher scores relative monolingual groups. There was not a significant interaction between diagnostic group and language exposure $\left(F(1.16)=0.79, p=0.39\right.$, partial $\left.n^{2}=0.05\right)$. For number of words produced there were no significant effects and all effect sizes were very small. Diagnostic group $\left(F(1.16)=1.04, p=0.32\right.$, partial $\left.n^{2}=0.03\right) ;$ language exposure group $(F(1.16)=0.66$, $p=0.43$, partial $\left.n^{2}=0.04\right)$; interaction $\left(F(1.16)=0.04, p=0.85\right.$, partial $\left.n^{2}=0.002\right)$.

Table 3 presents the scores obtained in macrostructure for each group. For macrostructure, results revealed a statistically significant main effect of diagnostic group $\left(F(1.16)=7.44, p=0.02\right.$, partial $\left.n^{2}=0.32\right)$, with the TD groups obtaining higher scores relative to the ASD groups, with extremely large effect size for TD monolinguals vs. ASD monolinguals $(d=2.38)$ and large effect size for TD bilinguals vs. ASD bilinguals $(d=0.94)$. There was no significant main effect of language $\left(F(1.16)=0.27, p=0.61\right.$, partial $\left.n^{2}=0.02\right)$, nor was the interaction significant $\left(F(1.16)=0.00, p=0.99\right.$, partial $\left.n^{2}=0.00\right)$. Inspection of Table 3 indicates although all groups were able to sequence the 3 pictures, TD and ASD groups differed in the number of actions mentioned and with respect to coherence or providing a narrative structure.

Microstructure scores are presented in Table 4. There were no statistically significant results. The effect of diagnostic group was however marginally significant $\left(F(1.16)=3.45, p=0.08\right.$, partial $\left.\eta^{2}=0.18\right)$, with TD participants exhibiting better performance than participants with ASD, with a very large effect size for TD monolinguals vs. ASD monolinguals $(d=1.31)$ and small effect size for TD bilinguals vs. ASD bilinguals $(d=0.29)$. There were no significant effects of language exposure group $\left(F(1.16)=0.20, p=0.66\right.$, partial $\left.\eta^{2}=0.01\right)$; nor a significant interaction $\left(F(1.16)=1.14, p=0.30\right.$, partial $\left.n^{2}=0.07\right)$. As reflected in Table 4, differences 


\begin{tabular}{|c|c|c|}
\hline 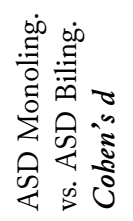 & $\begin{array}{l}\stackrel{+}{0} \\
\stackrel{1}{i}\end{array}$ & $\begin{array}{l}\infty \\
\infty \\
\stackrel{\varphi}{i}\end{array}$ \\
\hline 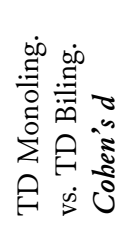 & 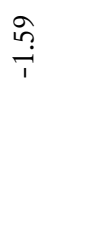 & $\begin{array}{l}\overrightarrow{\hat{n}} \\
\stackrel{i}{1}\end{array}$ \\
\hline 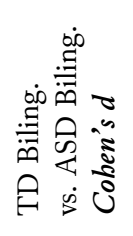 & $\stackrel{8}{\circ}$ & 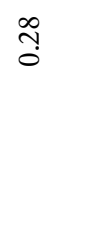 \\
\hline 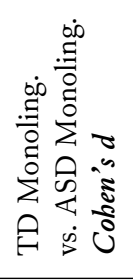 & $\begin{array}{l}\infty \\
\text { م. } \\
\text { iे }\end{array}$ & $\stackrel{\Omega}{o}$ \\
\hline 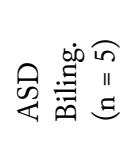 & 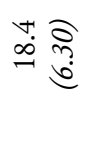 & 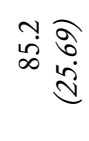 \\
\hline 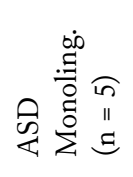 & 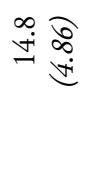 & 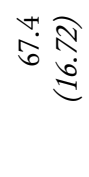 \\
\hline 目竞竞 & 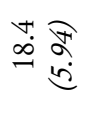 & 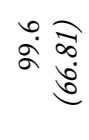 \\
\hline 园总 & $\begin{array}{l}0 \\
\stackrel{R}{0} \\
\stackrel{i}{n}\end{array}$ & 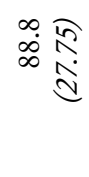 \\
\hline & 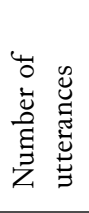 & 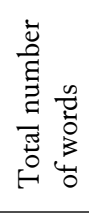 \\
\hline
\end{tabular}

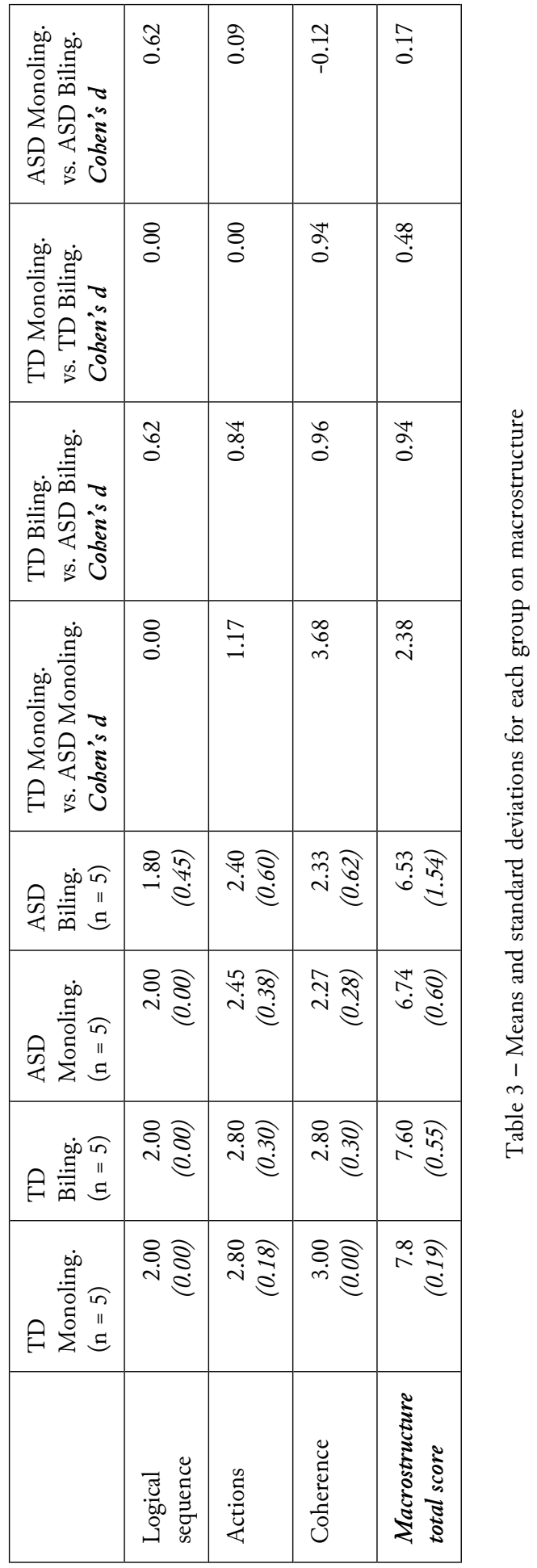


between groups were primarily with respect to the use of appropriate referential terms to introduce the main character, and in the appropriate use of conjunctions (coordinating and subordinating conjunctions). In these cases, TD monolinguals received the highest scores, followed by TD bilinguals, and then the ASD groups who performed fairly similarly.

Evaluative scores are presented in Table 5. There were no significant effects found between groups with respect to the elaboration total score: diagnostic group $\left(F(1.16)=1.56, p=0.23\right.$, partial $\left.n^{2}=0.09\right)$; language exposure group $\left(F(1.16)=0.31, p=0.59\right.$, partial $\left.n^{2}=0.02\right)$; interaction $(F(1.16)=0.08, p=0.79$, partial $\left.n^{2}=0.005\right)$. Inspection of Table 5 indicates this may be due to the low incidence (a mean of 1.87 out of a possible 6 points was the highest score observed, in the TD monolingual group), and high level of variability in these measures for the task we employed. Therefore, the null effect should be interpreted cautiously. While nonlinguistic elaborations were similar across groups with very small pairwise effect sizes, linguistic evaluative devices were higher in the TD than ASD groups, with large effect sizes for TD monolinguals vs. ASD monolinguals $(d=0.86)$ and TD bilinguals vs. ASD bilinguals $(d=1.00)$. Mental state terms were also employed numerically more often by TD than ASD groups, with medium effect sizes for TD monolinguals vs. ASD monolinguals $(d=0.72)$ and TD bilinguals vs. ASD bilinguals $(d=0.49)$. Monolinguals with ASD used numerically more linguistic evaluative devices $(d=1.17)$ and mental state terms $(d=0.50)$ than bilinguals with ASD, but this pattern was not evidenced between the TD bilingual and monolingual groups.

\section{Discussion}

The current study investigated how narrative skills are influenced by both having an ASD, and being bilingual, in school-age children who are speakers of Quebec French. Language production measures did not differ between diagnostic groups. However, we observed an unexpected effect where bilingual groups produced more utterances (but similar total number of words) in their short narratives than did monolinguals, despite having marginally lower receptive vocabulary scores in French. We observed reductions in macrostructure in the narratives of groups with ASD relative to those of TD groups, as well as a marginal decrease in microstructure in narratives produced by children with ASD relative to TD. Significant differences were not found in an evaluative total score, though there were some patterns of pairwise differences between groups that should be examined in larger samples. Notably, bilinguals and monolinguals from both diagnostic groups performed equally well on the aspects of macrostructure and microstructure that we measured.

\subsection{Macrostructure}

Results for macrostructure are in line with previous studies (Baixauli et al., 2016; Losh \& Capps, 2003; Norbury \& Bishop, 2003). TD children achieved greater scores 


\begin{tabular}{|c|c|c|c|c|c|}
\hline 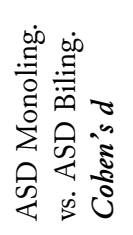 & $\stackrel{\infty}{\stackrel{\infty}{i}}$ & $\stackrel{\circ}{\circ}$ & $\stackrel{m}{0}$ & $\begin{array}{l}\vec{N} \\
\grave{i}\end{array}$ & $\begin{array}{l}\text { I̊ } \\
\text { în }\end{array}$ \\
\hline 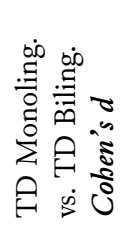 & $\stackrel{\stackrel{\sigma}{0}}{0}$ & సે & $\frac{0}{0}$ & $\underset{\overrightarrow{-}}{-\overrightarrow{0}}$ & $\underset{0}{\stackrel{N}{0}}$ \\
\hline 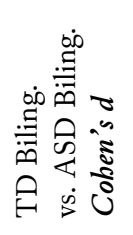 & $\stackrel{?}{\stackrel{9}{0}}$ & 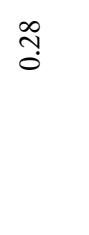 & $\stackrel{\uplus}{0}$ & $\stackrel{m}{0}$ & तે \\
\hline 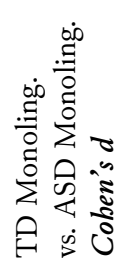 & $\stackrel{n}{\stackrel{n}{-}}$ & $\begin{array}{l}\hat{0} \\
0\end{array}$ & $\stackrel{n}{n}$ & $\stackrel{\infty}{\stackrel{+}{-}}$ & $\vec{m}$ \\
\hline 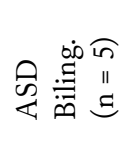 & 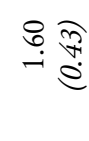 & 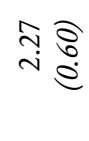 & 울 & $\stackrel{m}{\rightarrow} \underset{:}{0}$ & 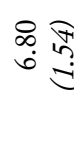 \\
\hline 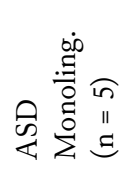 & 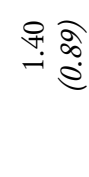 & 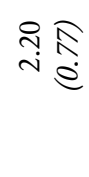 & $\stackrel{n}{\rightarrow} \stackrel{\vec{n}}{\stackrel{\overbrace{}}{e}}$ & 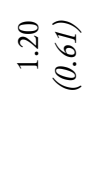 & ֶై \\
\hline 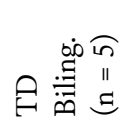 & 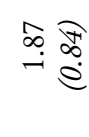 & 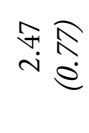 & $\stackrel{\vec{f}}{-} \underset{e}{\stackrel{\vec{f}}{e}}$ & 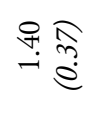 & 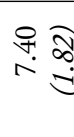 \\
\hline \multirow{2}{*}{ 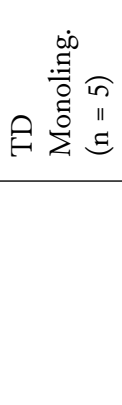 } & 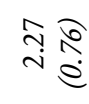 & 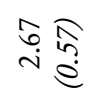 & $\stackrel{\overbrace{}}{\rightarrow} \stackrel{\pi}{e}$ & $\stackrel{\infty}{\rightarrow} \stackrel{\partial}{e}$ & 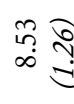 \\
\hline & 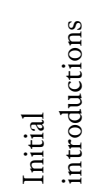 & 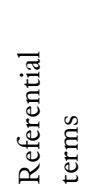 & 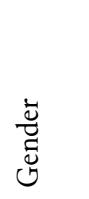 & 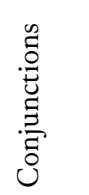 & 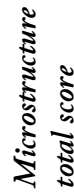 \\
\hline
\end{tabular}




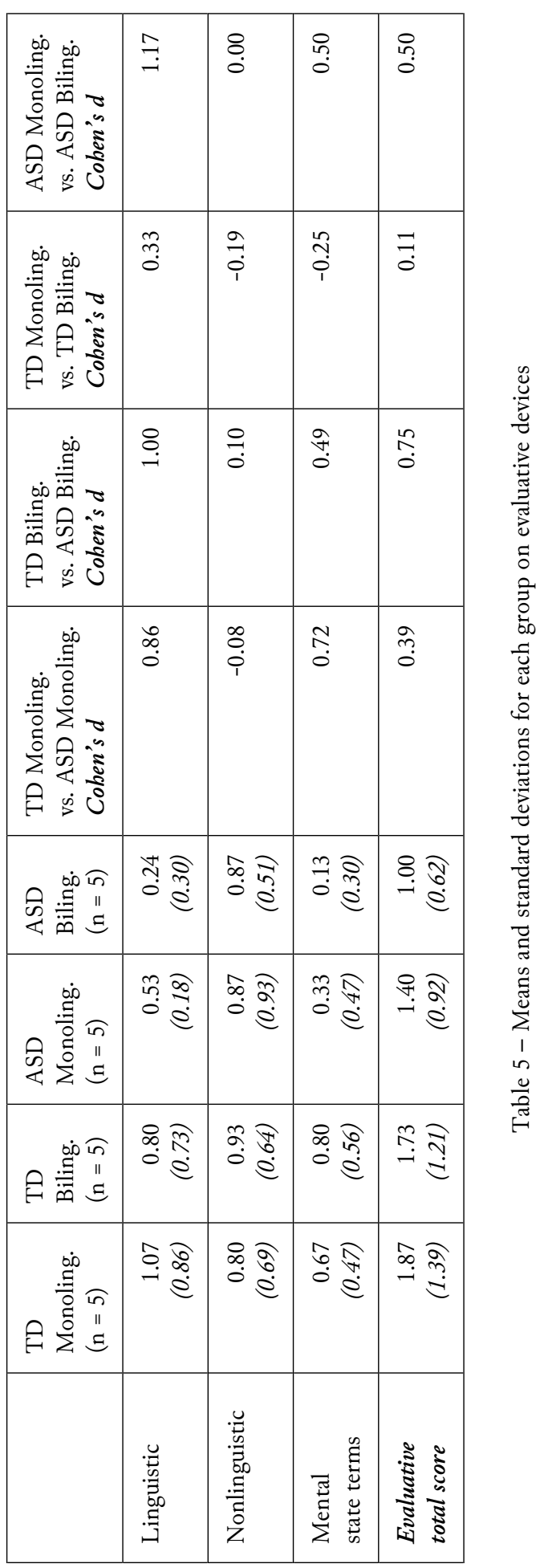


on coherence measures relative to ASD peers (TD monolinguals: Mean $=3.00$, $S D=0.00$; TD bilinguals: Mean $=2.80, S D=0.30$ ). The results are in accordance with Diehl et al.'s (2006) findings, in which ASD narratives were found to contain key story elements, but lacked coherence. A select few of the ASD narratives also contained irrelevant content, paralleling Loveland et al.'s (1990) findings.

[1] Example: 1611, irrelevant utterances

${ }^{*} \mathrm{CHI}$ : lui il fait une plante.

${ }^{*} \mathrm{CHI}$ : après il s'est $\mathrm{xxx}$.

${ }^{*} \mathrm{CHI}$ : il devient une monstre.

${ }^{*} \mathrm{CHI}$ : et lui a attrapé.

${ }^{*} \mathrm{CHI}$ : et $\mathrm{xxx}$ pris $\mathrm{xxx}$.

${ }^{*} \mathrm{CHI}$ : connais?

${ }^{*} \mathrm{CHI}$ : (re)garde chapeau.

A second observation was that, contrary to what is commonly observed in typical development, the outcome of the story was seldom omitted (Berman \& Slobin, 1994; Norbury \& Bishop, 2003). Instead, children with ASD were more likely to omit the medial event in the story, especially when it involved the completion of an action (e.g., baking the pie, making the castle; see Table 7 for description of the three actions in each sequence). These omissions might be due to the salience of the beginning and last actions within the picture stimuli used in our task.

[2] Example: 1622, no middle action

${ }^{*} \mathrm{CHI}$ : un garçon qui fait pousser des plantes.

${ }^{*} \mathrm{CHI}$ : il pousse mais après il l'entoure.

As expected, no significant differences were found between monolinguals and bilinguals on macrostructure, in line with prior results (Fiestas \& Peña, 2004; Squires et al., 2014; Uccelli \& Paéz, 2007). This supports the notion that there may be cross-linguistic transfer of macrostructure, thus facilitating access to knowledge of global narrative structure. For children with ASD, we did not find the advantages for bilinguals in story structure complexity and marginal reduction in ambiguous reference reported by Baldimtsi et al. (2016) and for TD and SLI (specific language impairment) by Tsimpli et al. (2016). This discrepancy could stem from: a) potential differences between the monolingual and bilingual ASD groups tested by Baldimtsi et al. (2016) in autism symptoms or SES; b) differences in the picture description task employed, wherein the current task involved ordering brief 3 picture sequences with one character, whereas Baldimtsi et al. (2016) employed the ENNI (Edmonton Narrative Norms Instrument) which involves more complex stories with 3 main characters and 8 pictures; and c) differences between the elements included for microstructure and macrostructure in the two studies. 


\subsection{Microstructure}

Comparisons between groups in microstructure did not reach significance, which would be expected given the brief, simple story to be told and that all participants had vocabulary scores in the normal range or above. Nevertheless, trends with some substantial effect sizes were present in microstructure submeasures. For one, monolingual TD children more consistently introduced the main character as a vivid novel referent (e.g., using a modified noun phrase or proper noun). ASD groups, on the other hand, were more likely to use pronouns in character introductions. These results mirror similar reports by Norbury and Bishop (2003). Children from all groups were more consistent in maintaining appropriate reference for objects than characters (e.g., the referential terms code), though there were some exceptions as in the following:

[3] Example: 1621, no change, maintaining a referential term

${ }^{*} \mathrm{CHI}$ : il met les il met les graines.

${ }^{*}$ CHI: il met de l'eau.

${ }^{*} \mathrm{CHI}$ : sur sa plante après sa \&pl sa plante pousse.

${ }^{*} \mathrm{CHI}: \mathrm{p}(\mathrm{u})$ is après sa plante tourne autours de lui.

Use of connectives for all groups falls within expectations of the typical developmental trajectory outlined by Vion and Colas (2005). Monolingual TD children used numerically more connectives than the other groups, which likely mirrors the fact that they had the highest vocabulary scores in French. Yet, in terms of quality, all groups used a variety of connectives to express sophisticated relationships between events. Rather than using et puis simply in a sequential or additive manner (a strategy that younger children often use as shown by Jisa [1984]), participants from all groups also employed adversative (e.g., mais), causal (e.g., parce que) and temporal (e.g., quand) connectives in their stories.

[4] Example: 1612, use of connective parce que

${ }^{*} \mathrm{CHI}$ : et là après sa détruit son \&s elle regarde là bas et elle regarde

voir là bas la après elle voit que toute l'eau a cassé son

château de sable.

${ }^{*} \mathrm{CHI}$ : parce qu'elle l'a faite trop proche de l'eau.

\subsection{Evaluative devices}

The present study also adds to the sparse literature regarding evaluative devices in bilingual and/or ASD narratives. Despite the lack of significant effects on the total evaluative score (and the low incidence of these elements compared to macro- and microstructure elements), there were a number of interesting patterns with respect to specific elements of evaluation. Linguistic evaluative devices (adding additional details not otherwise depicted in the picture stimuli) were more commonly observed in the TD vs. ASD groups. In regards to nonlinguistic evaluations, laughing, gesturing 
by pointing and smiling were common across all groups. No significant differences between language groups were observed, contrary to previous findings that bilinguals used a more animated storytelling style than monolinguals (Hoang et al., 2015).

[5] Example: 1605, linguistic evaluative device and adding details not depicted in the picture cards

${ }^{*} \mathrm{CHI}$ : le garçon arrose sa plante.

${ }^{*} \mathrm{CHI}$ : le garçon reviens pour voir sa plante et elle a grandit.

${ }^{*} \mathrm{CHI}$ : et quand il revient une heure plus tard elle a tout.

${ }^{*} \mathrm{CHI}$ : elle est tortiller dans \&s sur lui.

Mental state terms occurred very infrequently; however, children did produce some in their narratives although the picture-sequencing task was not specifically designed for eliciting mental state terms. They were produced to a lesser extent in the ASD groups compared to the TD groups. Emotion and desire terms occurred most frequently whereas perception, cognition and physiology terms were less common.

[6] Example: 1618, mental state term use

${ }^{*} \mathrm{CHI}$ : la petite fille fait une tarte aux pommes, aux fraises.

*CHI: quand elle avait terminé elle a dit "j’ai hâte de manger".

${ }^{*} \mathrm{CHI}$ : et après.

${ }^{*} \mathrm{CHI}$ : elle a pris une bouchée et elle a pas aimé.

\subsection{Implications for children with ASD}

Importantly, no main effects or interactions related to language exposure (bilingual vs. monolingual) were found for the three narrative components. The one difference we found with respect to language exposure was an increased number of utterances produced by bilingual relative to monolingual groups. Thus, bilingualism did not negatively impact narrative abilities in either group, as previously reported by multiple groups exploring narratives in Finnish, Swedish, English, Spanish and Greek (Kunnari et al., 2016; Squires et al., 2014; Tsimpli et al., 2016). This is a finding of particular importance for bilingual children with ASD, for whom we know very little about more open-ended expressive language skills. Together with recent evidence from Baldimtsi et al. (2016) on narratives, our findings on narrative production in bilinguals with ASD counter the idea that bilingual exposure may be harmful for language development in this population. Rather, these findings support bilingual education and child-rearing for children with ASD from bilingual families or societies. In such cases, limiting a child's linguistic environment to one language could result in significant negative social, emotional and linguistic repercussions (Fernandez y Garcia et al., 2012). When this language is not a native language for parents, they may become more reluctant to speak to their children, provide sub-optimal language models, or be less socially responsive, and in turn the child's language input may be reduced. Thus, one-language practices themselves may inadvertently be detrimental for development. 


\subsection{Limitations}

The picture-sequencing task employed here may have been helpful in reducing cognitive load, but the stimuli and procedure also had a number of limitations with respect to the elicitation of narratives. Since the pictures were shown to both the child and the experimenter, shared knowledge may have affected referential terms use and initial introductions of the characters. Some children from all groups used pronouns to introduce their character and continued to use that pronoun throughout the narrative, although TD monolinguals in particular generally produced more specific initial descriptions, even in this context. Similarly, the child might have omitted some actions, as it could be assumed that this was shared knowledge between the storyteller and the listener who both saw the picture cards.

The small sample size greatly limits the extent to which the results of statistical tests can be generalized, hence our emphasis on effect sizes. Our small sample is balanced by the methodological strength of the current study in testing four groups of children and ensuring that multiple key factors (age, NVIQ, vocabulary ability, maternal education, autism symptoms) were matched where possible or measured and reported, allowing for observed effects to be attributed to ASD diagnosis. Future studies are needed that examine larger sample sizes or make use of meta-analytic methods to produce generalizable results. In addition, future work should employ longer stories with multiple characters in hopes of eliciting mental states, use of elaborations, story grammar components, use of conjunctions, etc. in a richer narrative sample. Finally, both ASD and bilingualism fall on a broad spectrum, and results may not extend to children with ASD with intellectual ability, or to individuals from other contexts of bilingualism.

\subsection{Conclusion}

The current findings demonstrate no differences with respect to macrostructure, microstructure, and use of evaluative devices, in the narratives of 7- to 9-year-old bilinguals relative to monolinguals, for both ASD and TD groups. The one difference found related to language exposure was an increased number of utterances produced by bilinguals relative to monolinguals, despite having marginally lower receptive vocabulary scores. This adds to growing evidence in that bilingualism does not harm language development in children with ASD. Differences were found however between ASD and TD groups, in line with prior research, stemming in particular from reduced coherence measures in the ASD group. 


\section{References}

American Psychiatric Association 2013. Diagnostic and Statistical Manual of Mental Disorders: DSM-5. Washington: American Psychiatric Association Publishing [5th ed.].

Archibald, L.M. \& Joanisse, M.F. 2009. On the Sensitivity and Specificity of Nonword Repetition and Sentence Recall to Language and Memory Impairments in Children. Journal of Speech, Language, and Hearing Research 52 (4): 899-914.

Baixauli, I., Colomer, C., Roselló, B. \& Miranda, A. 2016. Narratives of Children with High-Functioning Autism Spectrum Disorder: A Meta-Analysis. Research in Developmental Disabilities 59: 234-254.

Baldimtsi, E., Peristeri, E., Tsimpli, I.M. \& Nicolopoulou, A. 2016. Bilingual Children with High Functioning Autism Spectrum Disorder: Evidence from Oral Narratives and Non-Verbal Executive Function Tasks. In J. Scotт \& D. Waughtal (eds.), Proceedings of the 40th Annual Boston University Conference on Language Development. Somerville: Cascadilla Press: 18-31.

Bamberg, M. \& Damrad-Frye, R. 1991. On the Ability to Provide Evaluative Comments: Further Explorations of Children's Narrative Competencies. Journal of Child Language 18 (3): 689-710.

Bamberg, M. \& Reilly, J. 1996. Emotion, Narrative and Affect: How Children Discover the Relationship between What to Say and How to Say It. In D.I. Slobin, J. Gerhard, A. Kyratzis \& J. Guo (eds.), Social Interaction, Social Context, and Language: Essays in Honor of Susan Ervin-Tripp. Hillsdale: L. Erlbaum: 329-341.

Bang, J., Burns, J. \& NAdig, A. 2013. Brief Report: Conveying Subjective Experience in Conversation: Production of Mental State Terms and Personal Narratives in Individuals with High Functioning Autism. Journal of Autism and Developmental Disorders 43 (7): 1732-1740.

Barac, R., Bialystok, E., Castro, D.C. \& Sanchez, M. 2014. The Cognitive Development of Young Dual Language Learners: A Critical Review. Early Childhood Research Quarterly 29 (4): 699-714.

Bartsch, K. \& Wellman, H.M. 1995. Children Talk about the Mind. New York: Oxford University Press.

Berman, R.A. 2009. Trends in Research on Narrative Development. In S.H. Foster-Cohen (ed.), Language Acquisition. Basingstoke - New York: Palgrave Macmillan: 294-318.

Berman, R.A. \& Slobin, D.I. 1994. Relating Events in Narrative: A Crosslinguistic Developmental Study. Hillsdale: L. Erlbaum.

Bialystok, E., Abutalebi, J., Baк, T.H., Burke, D.M. \& Kroll, J.F. 2016. Aging in Two Languages: Implications for Public Health. Aging Research Reviews 27: 56-60.

BLOM, E. 2010. Effects of Input on the Early Grammatical Development of Bilingual Children. International Journal of Bilingualism 14 (4): 422-446.

Buchweitz, A. \& Prat, C. 2013. The Bilingual Brain: Flexibility and Control in the Human Cortex. Physics of Life Reviews 10 (4): 428-443.

Capps, L., Losh, M. \& Thurber, C. 2000. "The Frog Ate the Bug and Made His Mouth Sad": Narrative Competence in Children with Autism. Journal of Abnormal Child Psychology 28 (2): 193-204. 
Chen, L. \& Yan, R. 2011. Development and Use of English Evaluative Expressions in Narratives of Chinese-English Bilinguals. Bilingualism Language and Cognition 14 (4): 570-578.

Conti-Ramsden, G., Botting, N. \& Faragher, B. 2001. Psycholinguistic Markers for Specific Language Impairment (SLI). The Journal of Child Psychology and Psychiatry 42 (6): 741-748.

Diehl, J.J., Bennetto, L. \& Young, E.C. 2006. Story Recall and Narrative Coherence of High-Functioning Children with Autism Spectrum Disorders. Journal of Abnormal Child Psychology 34 (1): 83-98.

Drysdale, H., Van der Meer, L. \& Kagohara, D. 2015. Children with Autism Spectrum Disorder from Bilingual Families: A Systematic Review. Review Journal of Autism and Developmental Disorders 2 (1): 26-38.

Ellis Weismer, S. \& Kover, S.T. 2015. Preschool Language Variation, Growth, and Predictors in Children on the Autism Spectrum. The Journal of Child Psychology and Psychiatry 56 (12): 1327-1337.

Fenson, L., Dale, P.S., Reznick, S.J., Bates, E., Thal, D.J., Pethick, S.J., Tomasello, M., Mervis, C.B. \& Stiles, J. 1994. Variability in Early Communicative Development. Monographs of the Society for Research in Child Development 59 (5): 1-185.

Fernandez y Garcia, E., Breslau, J., Hansen, R. \& Miller, E. 2012. Unintended Consequences: An Ethnographic Narrative Case Series Exploring Language Recommendations for Bilingual Families of Children with Autistic Spectrum Disorders. Journal of Medical Speech-Language Pathology 20 (2): 10-16.

Fiestas, C.E. \& PEÑA, E.D. 2004. Narrative Discourse in Bilingual Children: Language and Task Effects. Language, Speech, and Hearing Services in Schools 35 (2): 155-168.

GoEtz, P.J. 2003. The Effects of Bilingualism on Theory of Mind Development. Bilingualism: Language and Cognition 6 (1): 1-15.

GonZalez-BARRero, A. \& NADIG, A. under review. Vocabulary and Grammatical Skills of Bilingual Children with Autism Spectrum Disorders at School Age.

Hambly, C. \& Fombonne, E. 2012. The Impact of Bilingual Environments on Language Development in Children with Autism Spectrum Disorders. Journal of Autism and Developmental Disorders 42 (7): 1342-1352.

Hambly, C. \& Fombonne, E. 2014. Factors Influencing Bilingual Expressive Vocabulary Size in Children with Autism Spectrum Disorders. Research in Autism Spectrum Disorders 8 (9): 1079-1089.

Hawkins, R. \& Towell, R. 2001. French Grammar and Usage. London - New York: Routledge.

Hickmann, M. 1995. Discourse Organization and the Development of Reference to Person, Space, and Time. In P.J. Fletcher \& B. MacWhinney (eds.), The Handbook of Child Language. Oxford - Cambridge: B. Blackwell: 194-218.

Hickmann, M., Kail, M. \& Roland, F. 1995. Cohesive Anaphoric Relations in French Children's Narratives as a Function of Mutual Knowledge. First Language 15 (45): 277-300. 
Hoang, H., Nicoladis, E., Smithson, L. \& Furman, R. 2015. French-English Bilingual Children's Tense Use and Shift in Narration. International Journal of Bilingualism 20 (6): 750-769.

Iluz-Cohen, P. \& Walters, J. 2012. Telling Stories in Two Languages: Narratives of Bilingual Preschool Children with Typical and Impaired Language. Bilingualism: Language and Cognition 15 (1): 58-74.

JisA, H. 1984. French Preschoolers' Use of et pis (“and then”). First Language 5 (15): 169-184.

Karmiloff-Smith, A. 1981. The Grammatical Marking of Thematic Structure. In W. Deutsch (ed.), The Child's Construction of Language. London - New York: Academic Press: 194-218.

Karmiloff-Smith, A. 1986. Language and Cognitive Processes from a Developmental Perspective. Language and Cognitive Processes 1 (1): 61-85.

Kay-Raining Bird, E., Genesee, F. \& Verhoeven, L. 2016. Bilingualism in Children with Developmental Disorders: A Narrative Review. Journal of Communication Disorders 63: 1-14.

Kay-Raining Bird, E., Lamond, E. \& Holden, J. 2012. Survey of Bilingualism in Autism Spectrum Disorders. International Journal of Language and Communication Disorders 47 (1): 52-64.

Kimbrough Oller, D. 2005. The Distributed Characteristic in Bilingual Learning. In J. Cohen, K.T. McAlister, K. Rolstad \& J. MacSwan (eds.), ISB4: Proceedings of the 4th International Symposium on Bilingualism. Somerville: Cascadilla Press: 1744-1749. Available online: http://www.lingref.com/isb/4/137ISB4.PDF.

Kremer-SAdLIK, T. 2005. To Be or Not to Be Bilingual: Autistic Children from Multilingual Families. In J. Cohen, K.T. McAlister, K. Rolstad \& J. MacSwan (eds.), ISB4: Proceedings of the 4th International Symposium on Bilingualism. Somerville: Cascadilla Press: 1225-1234. Available online: http://www.lingref.com/isb/4/096ISB4.PDF.

Kristen, S., Vuori, M. \& Sodian, B. 2015. "I Love the Cute Caterpillar!” - Autistic Children's Production of Internal State Language across Contexts and Relations to Joint Attention and Theory of Mind. Research in Autism Spectrum Disorders 12: 22-33.

KunNARI, S., VälimaA, T. \& LAukKanEN-Nevala, P. 2016. Macrostructure in the Narratives of Monolingual Finnish and Bilingual Finnish-Swedish Children. Applied Psycholinguistics 37 (1): 123-144.

Labov, W. \& Waletzky, J. 1967. Narrative Analysis: Oral Versions of Personal Experience. In J. Helm (ed.), Essays on the Verbal and Visual Arts: Proceedings of the 1966 Annual Spring Meeting of the American Ethnological Society. Seattle - London: University of Washington Press: 12-44.

Lakens, D. 2013. Calculating and Reporting Effect Sizes to Facilitate Cumulative Science: A Practical Primer for T-Tests and ANOVAs. Frontiers in Psychology 4: 863. Available online: https://www.frontiersin.org/articles/10.3389/fpsyg.2013.00863/full.

Losh, M. \& CAPps, L. 2003. Narrative Ability in High-Functioning Children with Autism or Asperger's Syndrome. Journal of Autism and Developmental Disorders 33 (3): 239-251.

Loveland, K.A., McEvoy, R.E., Tunali, B. \& Kelley, M.L. 1990. Narrative Story Telling in Autism and Down's Syndrome. British Journal of Developmental Psychology 8 (1): 9-23. 
Lund, E.M., Kohlmeier, T.L. \& DuráN, L.K. 2017. Comparative Language Development in Bilingual and Monolingual Children with Autism Spectrum Disorder: A Systematic Review. Journal of Early Intervention 39 (2): 106-124.

MacWhinney, B. 2000. The CHILDES Project: Tools for Analyzing Talk. Mahwah - London: L. Erlbaum [3rd ed.].

Miller, J., Andriacchi, K., DiVall-Rayan, J. \& Lien, P. 2003. Narrative Scoring Scheme (NSS). See the NSS Scoring Guide available online: https://saltsoftware.com/ media/wysiwyg/codeaids/NSS_Scoring_Guide.pdf.

Nicoladis, E. \& GEnEsee, F. 1997. Language Development in Preschool Bilingual Children. Journal of Speech-Language Pathology and Audiology 21 (4): 258-270.

Norbury, C.F. \& Bishop, D.V.M. 2003. Narrative Skills of Children with Communication Impairments. International Journal of Language and Communication Disorders 38 (3): 287-313.

Paradis, J. \& Genesee, F. 1996. Syntactic Acquisition in Bilingual Children: Autonomous or Interdependent? Studies in Second Language Acquisition 18 (1): 1-25.

Paradis, J., Genesee, F. \& Crago, M.B. 2011. Dual Language Development and Disorders: A Handbook on Bilingualism and Second Language Learning. Baltimore - London Sydney: P.H. Brookes [2nd ed.].

Peal, E. \& Lambert, W.E. 1962. The Relation of Bilingualism to Intelligence. Psychological Monographs: General and Applied 76 (27): 1-23.

Pearson, B.Z. 2001. Logic and Mind in Spanish - English Children's Narratives. In L.T. Verhoeven \& S. Strömovist (eds.), Narrative Development in a Multilingual Context. Amsterdam - Philadelphia: J. Benjamins: 373-398.

PeArson, B.Z. 2002. Narrative Competence among Monolingual and Bilingual School Children in Miami. In D. Kimbrough Oller \& R.E. Eilers (eds.), Language and Literacy in Bilingual Children. Clevedon: Multilingual Matters: 135-174.

Pearson, B.Z., Fernández, S.C. \& Kimbrough Oller, D. 1993. Lexical Development in Bilingual Infants and Toddlers: Comparison to Monolingual Norms. Language Learning 43 (1): 93-120.

Pearson, B.Z. \& Villiers, P.A. De 2005. Child Language Acquisition: Discourse, Narrative, and Pragmatics. In K. BROwN (ed.), Encyclopedia of Language and Linguistics. Amsterdam - Boston - Heidelberg: Elsevier: 686-693 [2nd ed.].

Petersen, J.M., Marinova-Todd, S.H. \& Mirenda, P. 2012. Brief Report: An Exploratory Study of Lexical Skills in Bilingual Children with Autism Spectrum Disorder. Journal of Autism and Developmental Disorders 42 (7): 1499-1503.

Peterson, C. \& McCabe, A. 1991. On the Threshold of the Storyrealm: Semantic versus Pragmatic Use of Connectives in Narratives. Merrill-Palmer Quarterly 37 (3): 445-464.

Pickles, A., Anderson, D.K. \& Lord, C. 2014. Heterogeneity and Plasticity in the Development of Language: A 17-Year Follow-up of Children Referred Early for Possible Autism. The Journal of Child Psychology and Psychiatry 55 (12): 1354-1362.

Reilly, J., Klima, E.S. \& Bellugi, U. 1990. Once More with Feeling: Affect and Language in Atypical Populations. Development and Psychopathology 2 (4): 367-391.

RoID, G. \& Miller, L. 1997. Leiter International Performance Scale. Wood Dale: Stoelting. 
Rutter, M, Bailey, A. \& Lord, C. 2003. SCQ: The Social Communication Questionnaire. Torrance: Western Psychological Services.

SCHNEIDER, P. \& HAYwARD, D. 2010. Who Does What to Whom: Introduction of Referents in Children's Storytelling from Pictures. Language, Speech, and Hearing Services in Schools 41 (4): 459-473.

Secord, W.A., Wiig, E.H., Boulianne, L., Semel, E. \& Labelle, M. 2009. Évaluation clinique des notions langagières fondamentales - version pour francophones du Canada / Clinical Evaluation of Language Fundamentals - French Canadian Version. Toronto: Pearson Canada Assessment.

Shapiro, L.R. \& Hudson, J.A. 1991. Tell Me a Make-Believe Story: Coherence and Cohesion in Young Children's Picture-Elicited Narratives. Developmental Psychology 27 (6): 960-974.

Spinillo, A.G. \& Pinto, G. 1994. Children's Narratives under Different Conditions: A Comparative Study. British Journal of Developmental Psychology 12 (2): 177-193.

Squires, K.E., Lugo-Neris, M.J., Peña, E.D., Bedore, L.M., Bohman, T.M. \& Gillam, R.B. 2014. Story Retelling by Bilingual Children with Language Impairments and Typically Developing Controls. International Journal of Language and Communication Disorders 49 (1): 60-74.

SteIn, N.L. \& GLENN, C.G. 1979. An Analysis of Story Comprehension in Elementary School Children. In R.O. FreEdLE (ed.), New Directions in Discourse Processing. Norwood: Ablex: 53-120.

TAger-Flusberg, H. 1995. "Once Upon a Ribbit": Stories Narrated by Autistic Children. British Journal of Developmental Psychology 13 (1): 45-59.

Tager-Flusberg, H. \& Sullivan, K. 1995. Attributing Mental States to Story Characters: A Comparison of Narratives Produced by Autistic and Mentally Retarded Individuals. Applied Psycholinguistics 16 (3): 241-256.

Thordardottir, E. 2011. The Relationship between Bilingual Exposure and Vocabulary Development. International Journal of Bilingualism 15 (4): 426-445.

Thordardottir, E., Kehayia, E., Mazer, B., Lessard, N., Majnemer, A., Sutton, A., Trudeau, N. \& Chilingaryan, G. 2011. Sensitivity and Specificity of French Language and Processing Measures for the Identification of Primary Language Impairment at Age 5. Journal of Speech, Language, and Hearing Research 54 (2): 580-597.

Tsimpli, I.M., Peristeri, E. \& Andreou, M. 2016. Narrative Production in Monolingual and Bilingual Children with Specific Language Impairment. Applied Psycholinguistics 37 (Special Issue 1): 195-216.

UCCelli, P. \& PÁez, M.M. 2007. Narrative and Vocabulary Development of Bilingual Children from Kindergarten to First Grade: Developmental Changes and Associations among English and Spanish Skills. Language, Speech, and Hearing Services in Schools 38 (3): 225-236.

Valicenti-McDermott, M., Tarshis, N., Schouls, M., Galdston, M., Hottinger, K., Seijo, R., Shulman, L. \& Shinnar, S. 2013. Language Differences between Monolingual English and Bilingual English-Spanish Young Children with Autism Spectrum Disorders. Journal of Child Neurology 28 (7): 945-948. 
VION, M. \& ColAs, A. 1999. Maintaining and Reintroducing Referents in French: Cognitive Constraints and Development of Narrative Skills. Journal of Experimental Child Psychology 72 (1): 32-50.

Vion, M. \& Colas, A. 2005. Using Connectives in Oral French Narratives: Cognitive Constraints and Development of Narrative Skills. First Language 25 (1): 39-66.

Wigglesworth, G. 1990. Children's Narrative Acquisition: A Study of some Aspects of Reference and Anaphora. First Language 10 (29): 105-125. 


\section{Appendix $^{3}$}

\begin{tabular}{|c|c|c|c|c|c|}
\hline & Submeasure & 0 & 1 & 2 & 3 \\
\hline \multirow[t]{3}{*}{$\begin{array}{l}\text { Macro- } \\
\text { structure } \\
\text { Total } \\
\text { / } 8\end{array}$} & $\begin{array}{l}\text { Logical } \\
\text { sequence }\end{array}$ & $\begin{array}{l}\text { Does not } \\
\text { place pictures } \\
\text { in a logical } \\
\text { sequence. }\end{array}$ & $\begin{array}{l}\text { Arranges some } \\
\text { pictures (not } \\
\text { all) in a logical } \\
\text { sequence. }\end{array}$ & $\begin{array}{l}\text { Arranges all } \\
\text { three pictures } \\
\text { in correct } \\
\text { logical } \\
\text { sequence. }\end{array}$ & \\
\hline & $\begin{array}{l}\text { Description } \\
\text { of actions }\end{array}$ & & $\begin{array}{l}\text { Mentions } \\
\text { one action. }\end{array}$ & $\begin{array}{l}\text { Mentions two } \\
\text { main actions. }\end{array}$ & $\begin{array}{l}\text { Mentions } \\
\text { all three } \\
\text { main actions. }\end{array}$ \\
\hline & Coberence & & $\begin{array}{l}\text { Absence } \\
\text { of/ minimal } \\
\text { narrative; } \\
\text { names objects } \\
\text { and characters } \\
\text { but does not } \\
\text { provide a plot. }\end{array}$ & $\begin{array}{l}\text { Provides a } \\
\text { narrative, } \\
\text { but it is } \\
\text { ambiguous } \\
\text { and/or } \\
\text { incomplete. }\end{array}$ & $\begin{array}{l}\text { Provides a } \\
\text { good quality } \\
\text { narrative; } \\
\text { may be } \\
\text { short but is } \\
\text { complete. }\end{array}$ \\
\hline \multirow[t]{2}{*}{$\begin{array}{l}\text { Micro- } \\
\text { structure } \\
\text { Total } \\
\text { / } 10\end{array}$} & $\begin{array}{l}\text { Initial } \\
\text { introduction } \\
\text { of the main } \\
\text { character }\end{array}$ & $\begin{array}{l}\text { Incorrectly } \\
\text { refers to the } \\
\text { character. } \\
\text { e.g., le } \\
\text { monsieur for } \\
\text { la fille }\end{array}$ & $\begin{array}{l}\text { Names the } \\
\text { character } \\
\text { with only a } \\
\text { pronoun. } \\
\text { e.g., elle }\end{array}$ & $\begin{array}{l}\text { Names the } \\
\text { character using } \\
\text { a noun-phrase } \\
\text { with the } \\
\text { correct gender. } \\
\text { e.g., la fille }\end{array}$ & $\begin{array}{l}\text { Names the } \\
\text { character with } \\
\text { a definite/ } \\
\text { indefinite } \\
\text { noun-phrase } \\
\text { with a } \\
\text { modifier, } \\
\text { OR gives } \\
\text { a proper } \\
\text { name to the } \\
\text { character. } \\
\text { e.g., la petite } \\
\text { fille; Kathy }\end{array}$ \\
\hline & $\begin{array}{l}\text { Use of } \\
\text { referential } \\
\text { terms }\end{array}$ & & $\begin{array}{l}\text { Consistent } \\
\text { use of either } \\
\text { definite } \\
\text { descriptions or } \\
\text { pronouns with } \\
\text { no change } \\
\text { over the } \\
\text { sequence. } \\
\text { e.g., elle } \\
\text { remains as elle, } \\
\text { and la tarte } \\
\text { remains la } \\
\text { tarte }\end{array}$ & $\begin{array}{l}\text { Inconsistent } \\
\text { reduction } \\
\text { of forms } \\
\text { from definite } \\
\text { descriptions } \\
\text { to pronouns. } \\
\text { e.g., elle } \\
\text { remains as elle, } \\
\text { but une tarte } \\
\text { is becomes la } \\
\text { tarte }\end{array}$ & $\begin{array}{l}\text { Appropriately } \\
\text { moves from } \\
\text { definite/ } \\
\text { indefinite } \\
\text { reference to } \\
\text { pronouns, } \\
\text { OR indefinite } \\
\text { to definite } \\
\text { reference over } \\
\text { the sequence. } \\
\text { e.g., une } \\
\text { petaqite fille to } \\
\text { elle; une tarte } \\
\text { to la tarte }\end{array}$ \\
\hline
\end{tabular}

3. It should be noted that the examples included in this appendix are reported as transcribed, with no correction in spelling or grammar to the children's utterances. 


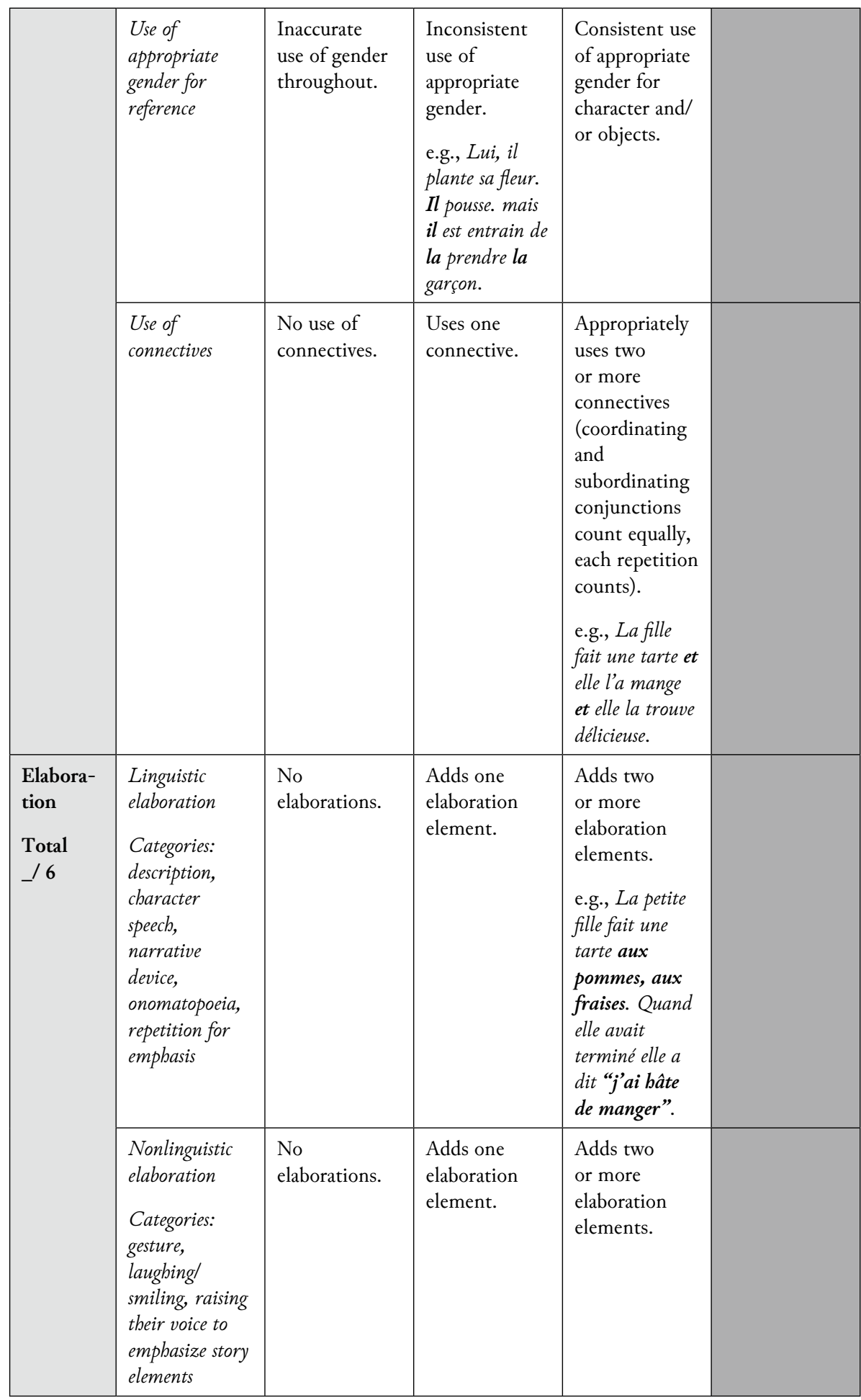




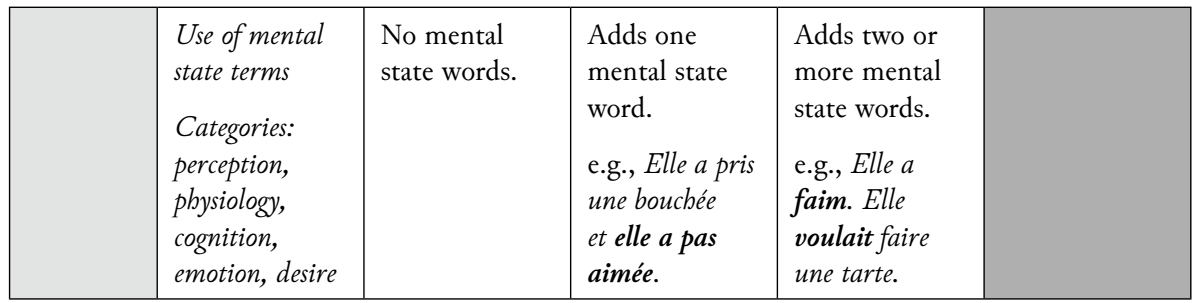

Table 6 - Coding scheme with examples

\begin{tabular}{|c|c|c|}
\hline \multicolumn{3}{|c|}{ Sequence 1} \\
\hline Action 1 options & Action 2 options & Action 3 options \\
\hline La fille fait un gâteau. & Elle l'a fini. & Elle le mange. \\
\hline La fille fait une pizza. & Elle a mis de la confiture. & Elle a coupé un morceau. \\
\hline \multicolumn{3}{|l|}{ La maman fait un gâteau. } \\
\hline \multicolumn{3}{|c|}{ Sequence 2} \\
\hline Action 1 options & Action 2 options & Action 3 options \\
\hline Le garçon arrose la plante. & La plante grossit. & La plante entoure le garçon. \\
\hline \multirow[t]{3}{*}{ Le garçon plante la plante. } & Il la regarde pousser. & La plante attaque le garçon. \\
\hline & Elle est devenue une fleur. & Elle s'accroche le garçon. \\
\hline & & $\begin{array}{l}\text { La fleur grandit jusqu'au cou } \\
\text { du garçon. }\end{array}$ \\
\hline \multicolumn{3}{|c|}{ Sequence 3} \\
\hline Action 1 options & Action 2 options & Action 3 options \\
\hline La fille construit un château. & Elle a fini. & $\begin{array}{l}\text { Une vague s'approche et détruit } \\
\text { le château. }\end{array}$ \\
\hline La fille fait un château. & Elle a tout construit. & Elle saute sur le château. \\
\hline La fille joue avec le sable. & & Elle détruit le cbâteau. \\
\hline \multicolumn{3}{|c|}{ Unconventional sequence 3} \\
\hline Une vague détruit le château. & $\begin{array}{l}\text { La fille commence à le } \\
\text { reconstruire. }\end{array}$ & Elle a fini. \\
\hline La fille construit un château. & Mais l'eau le détruit. & Elle commence à le refaire. \\
\hline La fille a construit un château. & $\begin{array}{l}\text { Elle a trébuché au-dessus de son } \\
\text { château. }\end{array}$ & Elle a cassé. \\
\hline La fille a construit un château. & $\begin{array}{l}\text { Elle a embarqué dedans le } \\
\text { château. }\end{array}$ & Elle le casse. \\
\hline
\end{tabular}

Table 7 - Sample of acceptable responses for actions in each sequence of cards 


\begin{tabular}{|l|l|}
\hline \multicolumn{2}{|c|}{ Conjunctions used } \\
\hline et & mais quand \\
\hline puis & après \\
\hline mais & alors là \\
\hline à cause que & ensuite \\
\hline parce que & pour que \\
\hline quand & jusqu'à \\
\hline juste à temps que & \\
\hline
\end{tabular}

Table 8 - List of conjunctions used in the children's narratives

\begin{tabular}{|l|l|l|l|l|}
\hline \multicolumn{5}{|c|}{ Mental state categories from Bang et al., 2013 } \\
\hline Perception & Physiology & Cognition & Emotion & Desire \\
\hline voir & avoir faim & $\begin{array}{l}\text { trouver } \\
\text { (e.g., elle la } \\
\text { trouve très bonne) }\end{array}$ & peur & vouloir \\
\hline regarder & & avoir l'envie & triste & essayer \\
\hline & & & folle & \\
\hline & & & aimer & \\
\hline & & & avoir hâte & \\
\hline & & & content & \\
\hline
\end{tabular}

Table 9 - List of mental state terms mentioned in the children's narratives 